\title{
Diversity for Tree Growing Habit in the Natural Population of Pecan Nut (Carya illinoensis K.) in Jammu Province, India
}

\author{
Sohnika Rani*, Arti Sharma, V.K. Wali, Kiran Kour, \\ Manish Sharma and Rucku Gupta
}

Faculty of Agriculture, Sher-e-Kashmir University of Agricultural Sciences and Technology of
Jammu, Chatha. J\&K, India

*Corresponding author

\begin{abstract}
A B S T R A C T
The present investigation entitled diversity for growth habit in the natural population of pecan nut (Carya illinoensis K.) in the Jammu province was carried out in order to document the available genetic variability in pecan nut germplasm and to select elite pecan

\begin{tabular}{|c|}
\hline Keywords \\
\hline $\begin{array}{l}\text { Pecan nut, } \\
\text { Diversity, Tree } \\
\text { vigour }\end{array}$ \\
\hline Article Info \\
\hline $\begin{array}{l}\text { Accepted: } \\
20 \text { December } 2017 \\
\text { Available Online: } \\
10 \text { January } 2018\end{array}$ \\
\hline
\end{tabular}
nut genotypes possessing superior attributes and quality traits. During the survey, data was recorded on sixty (sixty) pecan nut trees growing in different areas of Rajouri and Poonch districts of Jammu province. Remarkable variability was observed in seedling pecan nut trees for different morphological, nut and kernel characters. Similarly, variations were also reported for other characters viz., tree vigour, growth habit, density of branching and one year old. Studies on tree vigour revealed substantial variability among the seedling raised pecan nut genotypes. In this study it was found that 47 genotypes $(78.33 \%)$ were strong and $13(21.67 \%)$ were medium in vigour. $17(28.33 \%)$ genotypes were observed to have upright growth habit, $28(46.67 \%)$ have semi-upright and $15(25.00 \%)$ were spreading growth habit. $6(10.00 \%)$ genotypes possessed sparsely dense canopy, 15 genotypes (25.00\%) exhibited medium and 39 genotypes $(65.00 \%)$ had highly dense canopy. Among sixty genotypes $17(28.33 \%)$ were observed to have greenish brown colour of one year old shoot colour, $25(41.67 \%)$ were having medium brown and $18(30.00 \%)$ having brown colour of one year old shoot colour.
\end{abstract}

\section{Introduction}

The Pecan nut [Carya illinoensis (Wangenheim) C. Koch] is one of the better known hickories. It is also called sweet Pecan and belongs to the family "Juglandaceae". Pecan is native to North America and also exists in Texas and North of Mexico (Andersen and Crocker, 2012). In India, pecans were introduced from USA by Punjab government in 1937. Eight cultivars were planted at Govt. Fruit Farm, Palmpur, Himachal Pradesh, which became major source of planting material in Himalayan region. At present pecan nut is one of the most important temperate nuts grown in India. In India, it is mainly grown in Jammu and Kashmir and Himachal Pradesh. The total area under pecan nut production is increasing due its high economic returns and adaptation to intermediate zone of Jammu (Ravindran et al., 2006). In India, it is grown over an area of 1 
thousand ha with the production of about 1 thousand MT (Anonymous, 2016a). The area under pecan nut in Jammu region is around 413 ha with production of about 85 MT in 2016-17 (Anonymous, 2016b).

Pecan nut has the recognition of being called "queen of nuts" because of its excellent kernel characteristics. Pecan having (flavor, 65-70\% fats, $8-10 \%$ proteins, high in phosphorous, potassium and vitamins $\mathrm{A}, \mathrm{C}, \mathrm{E}$ and $\mathrm{B}$ complex) is superior to walnut in quality and thrives best in areas which are considered lower and hotter for walnut cultivation (Singh et al., 2011). Though introduced in Palmpur, Himachal Pradesh, way back in this nut crop could not assume commercial status for the want of suitable cultivars among orchardists. Nevertheless, there is huge potential of this nut crop to commercialize being hardy to climatic vagaries and having export value. The existing population at Poonch, Rajouri, Kathua, Udhampur and Doda comprising the trees of seedling origins exhibit tremendous variability in growth, yield and quality attributes, thereby, providing a platform for exploitation of vast gene pool. Meager efforts have been made for selection of superior seedling pecan genotypes with desirable traits especially economically important nut and kernel traits.

The motivation behind this study is to examine the degree of diversity in pecan nut trees from different areas of Jammu province. These results will provide guidance about effective management, conservation, and improvement of pecan nut resources. In addition, the recent trends of expanding agriculture, increased urbanization and gigantic population growth are adding continuously to the extinction and genetic erosion of valuable pecan nut germplasm. Thus, there is a crucial need for exploration and conservation of the existing high quality pecan nut germplasm growing in this region.
The present study was conducted on pecan nut genotypes/selections by surveying different areas of Poonch, Rajouri and Jammu districts so as to estimate the extent of genetic relationship by studying tree morphological character.

\section{Materials and Methods}

The present investigation was carried out during the year 2015-2016 at different selected pecan nut growing areas of Jammu province. The study areas fall in Rajouri, Poonch and Jammu districts. Rajouri is situated at $33.38^{\circ}$ north latitude and $74.3^{\circ}$ east longitude at an altitude of 914 meters above sea level. Poonch is situated at $33.77^{\circ}$ north latitude and $74.10^{\circ}$ east longitude at an altitude of 981 meters above sea level. Miran Sahib of Jammu district is situated at $32.65^{\circ}$ north latitude and $74.81^{\circ}$ east longitude at an altitude of 284 meters above mean sea level.

Survey was done from major pecan nut growing districts viz., Rajouri and Poonch of Jammu province of Jammu and Kashmir state, to select promising accession among the diverse pecan nut genotypes and assess variability in their tree morphological characteristics. During the survey to get firsthand information local inhabitants and district horticulture offices were consulted about production and availability of pecan nut of seedling origin genotypes grown in areas at various places. The location was selected with respect to the availability of diversity in seedling pecan nut genotypes. On the basis of preliminary field observations and interactions with owners, the trees which were bearing extremely small sized, poor quality nuts and low yielding were not included. Finally, plants of sixty (60) seedling origin pecan nut genotypes with divergent tree characters were selected. Codes were allotted to each genotypes on the basis of their location (as SKJPP stands for SKUAST-Jammu pecan nut 
poonch, SKJPM stands for SKUAST-Jammu pecan nut Miran Sahib and SKJPR stands for SKUAST-Jammu pecan nut Rajouri and number were allotted for identification) and geo tagging was done for selected plants. Regular visits were made and observation on different tree characters i.e., tree vigour, density of canopy, tree growth habit and one year old shoot colour were made at different stages of plant growth using different pecan nut descriptors given by UPOV (International union for the protection of new varieties of plants) guidelines recently published in 2014 (UPOV, 2014). Tree vigour was observed as the overall abundance of branches during the dormant period and rated as 3 (weak), 5 (medium) and 7 (strong). The density of canopy of the plant was observed as the overall abundance of branches during the dormant period and was graded 3 (sparse), 5 (medium) and 7 (dense). Tree growth habit was classified as 1 (upright), 2(semi-upright) and 3(spreading). One year old shoot colour was visually observed and was rated as 1 (greenish brown), 2 (medium brown) and 3 (brown).

\section{Results and Discussion}

Tree characteristics are very important as far as diversity is concerned. In this study seedling pecan nut trees surveyed from different locations showed variability in tree characters.

Based on results presented in (Table 1 and Table 2) tree vigour the genotypes varied between strong, medium and weak. Out of 60 pecan nut genotypes studied 13 (21.67\%) genotypes had medium tree vigour while remaining 47 (78.33\%) had strong tree vigour. None of the selection was having weak tree vigour. Maximum seedling pecan nut trees were strong in vigour. Higher percentage of strong vigour in seedling trees may be attributed to their genetic constitution.
The tree growth habit also varied and was observed as upright, semi-upright and spreading. Out of 60 pecan nut genotypes 17 $(28.33 \%)$ seedling origin pecan nuts had upright type of tree habit, 28 (46.67\%) had semi-upright type of tree growth habit while remaining $15(25.00 \%)$ had spreading tree growth habit.

Maximum (28) were semi-upright in growth habit. These findings are in consonance with the findings of Akhiani et al., (2017) where they observed that out of 30 walnut seedlings maximum (19) trees were semi-upright in growth habit. In a similar study, Sharma (1977) and Grauke and Thompson (1996) observed spreading, semi-spreading and erect growth habit in pecan.

The accessions showed variation in density of canopy i.e., sparse, medium and dense. Out of sixty seedling origin pecan nut genotypes 6 $(10.00 \%)$ were having sparse canopy, 15 (25.00\%) were having medium dense canopy and $39(65.00 \%)$ were having dense canopy.

Maximum (39) were having highly dense canopy. These results are similar to the results of Lone (2017), who observed that out of 150 seedling genotypes of walnut maximum (65) were having dense canopy.

One year old shoot colour was categorised as greenish brown, medium brown and brown with greenish brown observed in 17 (28.33\%) seedling origin pecan nut, medium brown in $25(41.67 \%)$ genotypes and brown in 18 $(30.00 \%)$ genotypes. Out of 60 seedling pecan nut trees maximum were having medium brown.

In a similar study Sharma (1997) observed that colour of one year old shoot varied from medium brown, greenish brown to brown in walnut seedling trees growing in Himachal Pradesh. 
Table.1 Tree characteristics of pecan nut (Carya illinoensis K.) selections

\begin{tabular}{|c|c|c|c|c|c|c|c|}
\hline S. No & & Selection & Tree vigour & Growth Habit & Dens & ty of canopy & $\begin{array}{l}\text { One year old } \\
\text { shoot colour }\end{array}$ \\
\hline 1 & & SKJPR 1 & 5 & 2 & & 5 & 2 \\
\hline 2 & & SKJPR 2 & 7 & 1 & & 5 & 2 \\
\hline 3 & & SKJPR 3 & 5 & 2 & & 5 & 3 \\
\hline 4 & & SKJPR 4 & 7 & 1 & & 3 & 2 \\
\hline 5 & & SKJPR 5 & 7 & 3 & & 7 & 2 \\
\hline 6 & & SKJPR 6 & 5 & 1 & & 3 & 2 \\
\hline 7 & & SKJPR 7 & 5 & 1 & & 3 & 3 \\
\hline 8 & & SKJPP 8 & 7 & 3 & & 7 & 3 \\
\hline 9 & & SKJPP 9 & 5 & 1 & & 5 & 3 \\
\hline 10 & & SKJPP 10 & 5 & 1 & & 5 & 3 \\
\hline 11 & & SKJPP 11 & 7 & 2 & & 7 & 3 \\
\hline 12 & & SKJPP 12 & 7 & 2 & & 5 & 2 \\
\hline 13 & & SKJPP 13 & 7 & 2 & & 5 & 2 \\
\hline 14 & & SKJPP 14 & 5 & 1 & & 3 & 3 \\
\hline 15 & & SKJPP 15 & 7 & 2 & & 3 & 2 \\
\hline 16 & & SKJPP 16 & 5 & 3 & & 3 & 2 \\
\hline 17 & & SKJPP 17 & 5 & 1 & & 7 & 1 \\
\hline 18 & & SKJPP 18 & 5 & 1 & & 5 & 2 \\
\hline 19 & & SKJPP 19 & 7 & 1 & & 7 & 2 \\
\hline 20 & & SKJPP 20 & 7 & 1 & & 7 & 2 \\
\hline \multicolumn{8}{|l|}{ Legend } \\
\hline Tree vigour & Note & Growth habit & Note & Density of canopy & Note & $\begin{array}{l}\text { One year old } \\
\text { shoot colour }\end{array}$ & Note \\
\hline Strong & 7 & Upright & 1 & Sparse & 3 & $\begin{array}{c}\text { Greenish } \\
\text { brown }\end{array}$ & 1 \\
\hline Medium & 5 & Semi-upright & 2 & Medium & 5 & $\begin{array}{l}\text { Medium } \\
\text { brown }\end{array}$ & 2 \\
\hline Weak & 3 & Spreading & 3 & Dense & 7 & Brown & 3 \\
\hline
\end{tabular}


Contd.......

Table.1 Tree characteristics of pecan nut (Carya illinoensis K.) selections

\begin{tabular}{|c|c|c|c|c|c|c|c|}
\hline S. No & & Selection & Tree vigour & Growth Habit & \multicolumn{2}{|c|}{ Density of canopy } & $\begin{array}{l}\text { One year old } \\
\text { shoot colour }\end{array}$ \\
\hline 21 & \multicolumn{2}{|r|}{ SKJPM 21} & 7 & 3 & \multicolumn{2}{|r|}{7} & 3 \\
\hline 22 & & SKJPP 22 & 7 & 3 & \multicolumn{2}{|r|}{7} & 2 \\
\hline 23 & & SKJPP 23 & 7 & 1 & \multicolumn{2}{|r|}{7} & 2 \\
\hline 24 & & SKJPP 24 & 5 & 2 & \multicolumn{2}{|r|}{7} & 1 \\
\hline 25 & & SKJPP 25 & 5 & 1 & \multicolumn{2}{|r|}{7} & 1 \\
\hline 26 & & SKJPP 26 & 7 & 3 & \multicolumn{2}{|r|}{7} & 2 \\
\hline 27 & & SKJPP 27 & 7 & 3 & \multicolumn{2}{|r|}{5} & 3 \\
\hline 28 & & SKJPP 28 & 7 & 2 & \multicolumn{2}{|r|}{5} & 2 \\
\hline 29 & & SKJPP 29 & 7 & 2 & \multicolumn{2}{|r|}{5} & 2 \\
\hline 30 & & SKJPP 30 & 7 & 2 & \multicolumn{2}{|r|}{7} & 1 \\
\hline 31 & & SKJPP 31 & 7 & 2 & \multicolumn{2}{|r|}{7} & 3 \\
\hline 32 & & SKJPP 32 & 7 & 2 & \multicolumn{2}{|r|}{7} & 3 \\
\hline 33 & & SKJPP 33 & 7 & 1 & \multicolumn{2}{|r|}{5} & 3 \\
\hline 34 & & SKJPP 34 & 7 & 2 & \multicolumn{2}{|r|}{7} & 1 \\
\hline 35 & & SKJPP 35 & 7 & 2 & \multicolumn{2}{|r|}{7} & 2 \\
\hline 36 & & SKJPP 36 & 7 & 2 & & 7 & 2 \\
\hline 37 & & SKJPP 37 & 7 & 2 & & 7 & 1 \\
\hline 38 & & SKJPP 38 & 7 & 3 & & 7 & 2 \\
\hline 39 & & SKJPP 39 & 7 & 2 & & 7 & 1 \\
\hline 40 & & SKJPP 40 & 7 & 2 & & 7 & 1 \\
\hline Legend & & & & & & & \\
\hline Tree vigour & Note & Growth habit & Note & Density of canopy & Note & $\begin{array}{l}\text { One year old } \\
\text { shoot colour }\end{array}$ & Note \\
\hline Strong & 7 & Upright & 1 & Sparse & 3 & $\begin{array}{c}\text { Greenish } \\
\text { brown }\end{array}$ & 1 \\
\hline Medium & 5 & Semi-upright & 2 & Medium & 5 & Medium brown & 2 \\
\hline Weak & 3 & Spreading & 3 & Dense & 7 & Brown & 3 \\
\hline
\end{tabular}


Contd.........

Table.1 Tree characteristics of pecan nut (Carya illinoensis K.) selections

\begin{tabular}{|c|c|c|c|c|c|c|c|}
\hline S. No & & Selection & Tree vigour & Growth Habit & \multicolumn{2}{|c|}{ Density of canopy } & $\begin{array}{l}\text { One year old } \\
\text { shoot colour }\end{array}$ \\
\hline 41 & & SKJPP 41 & 7 & 3 & & 7 & 3 \\
\hline 42 & & SKJPP 42 & 7 & 3 & & 7 & 1 \\
\hline 43 & & SKJPP 43 & 7 & 2 & & 7 & 1 \\
\hline 44 & & SKJPP 44 & 5 & 2 & & 5 & 1 \\
\hline 45 & & SKJPP 45 & 7 & 2 & & 5 & 2 \\
\hline 46 & & SKJPP 46 & 7 & 2 & & 7 & 3 \\
\hline 47 & & SKJPP 47 & 7 & 1 & & 5 & 1 \\
\hline 48 & & SKJPP 48 & 7 & 1 & & 7 & 2 \\
\hline 49 & & SKJPP 49 & 7 & 2 & & 7 & 2 \\
\hline 50 & & SKJPP 50 & 7 & 2 & & 7 & 2 \\
\hline 51 & & SKJPP 51 & 7 & 3 & & 7 & 1 \\
\hline 52 & & SKJPP 52 & 7 & 3 & & 7 & 3 \\
\hline 53 & & SKJPP 53 & 7 & 3 & & 7 & 3 \\
\hline 54 & & SKJPP 54 & 7 & 2 & & 7 & 3 \\
\hline 55 & & SKJPP 55 & 7 & 3 & & 7 & 1 \\
\hline 56 & & SKJPP 56 & 7 & 2 & & 7 & 1 \\
\hline 57 & & SKJPP 57 & 7 & 2 & & 7 & 1 \\
\hline 58 & & SKJPP 58 & 7 & 3 & & 7 & 2 \\
\hline 59 & & SKJPP 59 & 7 & 2 & & 7 & 3 \\
\hline 60 & & SKJPP 60 & 7 & 1 & & 7 & 1 \\
\hline \multicolumn{8}{|l|}{ Legend } \\
\hline Tree vigour & Note & Growth habit & Note & Density of canopy & Note & $\begin{array}{l}\text { One year old } \\
\text { shoot colour }\end{array}$ & Note \\
\hline Strong & 7 & Upright & 1 & Sparse & 3 & $\begin{array}{c}\text { Greenish } \\
\text { brown }\end{array}$ & 1 \\
\hline Medium & 5 & Semi-upright & 2 & Medium & 5 & Medium brown & 2 \\
\hline Weak & 3 & Spreading & 3 & Dense & 7 & Brown & 3 \\
\hline
\end{tabular}




\begin{tabular}{|l|l|c|c|}
\hline \multicolumn{2}{|c|}{ Table.2 Summary of frequency of tree characters of pecan nut (Carya illinoensis K.) } \\
selections
\end{tabular}

The North western Himalayan region is one of the richest and most diverse gene pool of the cultivated pecan nuts. The success of any breeding programme depends on the presence of sufficient genetic variability to pursue effective selection. It is necessary to assess the relative magnitude of the existing genetic diversity in order to use such information together with other selection parameters for the improvement of fruit yield and other quality parameters of any fruit crop through adoption of an effective breeding approach. The extent of genetic variability indicates the potential of exercising selection of a particular genotype. Knowledge of the extent of diversity for tree phenology traits in pecan nut populations (seedling origin) and subsequent identification of adapted superior genotypes/cultivars as potential donors for yield will serve as pertinent source of superior parents for further breeding programme in pecan nut.

\section{References}

Akhiani, S., Afshari, H. Parvaneh, T. 2017. Evaluation of some phenological and pomological characteristics of selected Walnut genotypes from Shahroud-Iran.
Journals of Nuts, 8(01): 21-30.

Andersen, P. C. and T. E. Crocker. 2012. The pecan tree. EDIS Publication HS982, 17 pp. Department of Horticultural Sciences, Institute of Food and Agricultural Sciences, University of Florida, Gainesville, FL.

Anonymous. 2016a. Indian Horticulture Database. National Horticulture Board, Gurgoan

Anonymous. 2016b. Statement of J\&K, Department of Horticulture, Jammu.

Grauke, L. J. and Thompson, T. E. 1996. In Fruit Breeding vol. III: Nuts ed Janick, J. and J. N. Moore, Purdue Univ. Press, USA, pp. 185-239.

Lone, I. A. 2017. Estimation of variability and genetic parameters for kernel quality traits (protein and oil content) in the seedling raised natural walnut (Juglans regia L.) population in the Kashmir valley. International Journal of plant sciences, 12(2): 258-261.

Sharma, R. K. 1977. Studies on genetic variability in respect to tree and fruit characters in seedling pecan. M.Sc Thesis, Himachal Pradesh Agriculture University, Solan.

Singh, D., Kumar, K., Sharma, S. D. and 
Sharma, V. K. 2011. Selection of indigenous pecan [Carya illinoensis (Wang.) K. Koch.] Trees for better nut and kernel quality characters. Journal of Hill Agriculture, 2(1): 85-89.

UPOV, 2004. International union for the protection of new varieties of plants. Guidelines for the conduct of tests for distinctness, uniformity and stability. Pecan nut (Carya Illinoensis K.). UPOV-TG/Pecan (Proj.10). Geneva, pp. $1-26$.

\section{How to cite this article:}

Sohnika Rani, Arti Sharma, V.K. Wali, Kiran Kour, Manish Sharma and Rucku Gupta. 2018. Diversity for Tree Growing Habit in the Natural Population of Pecan Nut (Carya illinoensis K.) in Jammu Province, India. Int.J.Curr.Microbiol.App.Sci. 7(01): 2760-2767.

doi: https://doi.org/10.20546/ijcmas.2018.701.331 